\title{
CRITICAL EVALUATION OF MODIFIED-RELEASE FORMULATION CONTAINING SILYBUM MARIANUM EXTRACT FOR ORAL APPLICATION
}

\author{
DÁVID SINKA ${ }^{1 \#}$, ALEXANDRA HAGYMÁSI $^{1}$, PÁLMA FEHÉR $^{1}$, ZOLTÁN UJHELYI ${ }^{1}$, \\ MIKLÓS VECSERNYÉS ${ }^{1}$, FERENC FENYVESI ${ }^{1}$, JUDIT VÁRADI ${ }^{1}$, GÁBOR VASVÁRI ${ }^{1}$, \\ TÜNDE JURCA ${ }^{2}$, SEBASTIAN NEMETH ${ }^{2 \#}$, DANIELA ELENA POPA ${ }^{3 \#}$, ILDIKÓ BÁCSKAY ${ }^{1 *}$ \\ ${ }^{I}$ Department of Pharmaceutical Technology, Faculty of Pharmacy, University of Debrecen, Debrecen, Hungary \\ ${ }^{2}$ Department of Pharmacy, Faculty of Medicine and Pharmacy, University of Oradea, Oradea, Romania \\ ${ }^{3}$ Department of Drug Control, Faculty of Pharmacy, "Carol Davila" University of Medicine and Pharmacy, Bucharest, \\ Romania
}

*corresponding author: bacskay.ildiko@pharm.unideb.hu

${ }^{\#}$ Authors with equal contribution.

Manuscript received: December 2018

\begin{abstract}
Silymarin is the extract of active ingredients of the plant Silybum marianum. It is used in medicine for curing or preventing liver and gall diseases for thousands of years. Silymarin has a low solubility and permeability, belongs to BCS class IV. Its current pharmacotherapy means conventional dosage forms such as capsules, but it results in low bioavailability. Our main goals through the research were to formulate matrix tablets with silymarin as active ingredient. We used different carbopols as matrix-forming polymers. The complexation of silymarin with different $\beta$-cyclodextrins was intended to increase the solubility of the active ingredient. By achieving sustained release, our aim was to offer a better alternative than the conventional unsuccessful oral therapy. Comparing the results of our research, we could select the carbopol-cyclodextrin combination with the optimal drug release from the twenty different compounds. With these compositions, more than $85 \%$ of the silymarin was dissolved. The cytocompatibility of our product was proven, and the technology provided much better bioavailability than the conventional silymarin therapy.
\end{abstract}

\section{Rezumat}

Silimarina reprezintă extractul de ingrediente active din planta Silybum marianum, care de mii de ani se folosește în medicina tradițională pentru prevenirea și vindecarea bolilor hepatice și biliare. Silimarina are o solubilitate și permeabilitate scăzută, aparține clasei IV BCS. Farmacoterapia actuală constă în forme de dozare convenționale, cum ar fi capsule, dar care preintă o biodisponibilitate scăzută. Cercetările noastre au avut ca obiectiv principal formularea de comprimate matrix cu silimarină ca ingredient activ. Am folosit diferiți carbopoli ca polimeri care formează matrix. Complexarea silimarinei cu diferite $\beta$-ciclodextrine a avut rolul de a crește solubilitatea ingredientului activ. Prin realizarea eliberării susținute, scopul nostru a fost să oferim o alternativă mai bună decât terapia convențională orală. Comparând rezultatele cercetării noastre, putem scoate în evidență combinația carbopol-ciclodextrină cu eliberarea optimă a medicamentului din cele douăzeci de compuși diferiți studiaţi. $\mathrm{Cu}$ aceste compoziţii, mai mult de $85 \%$ din silimarină a fost dizolvată. Citocompatibilitatea produsului nostru a fost dovedit, tehnologia oferind o biodisponibilitate mult mai bună decât terapia convențională cu silimarina.

Keywords: modified-release, Silybum marianum, cyclodextrin, HPBCD, Caco-2 cells

\section{Introduction}

Silymarin is the active pharmaceutical ingredient (API) of the plant Silybum marianum (milk thistle). It is a flavonolignan complex, having the attention of scientists since the beginning of the flavonolignan researches [4]. Its components were separated by high performance liquid chromatography/tandem mass spectrometry. The main bioactive ingredients included silychristins $A$ and $\mathrm{B}$, silydianin, silybin $\mathrm{A}$ and $\mathrm{B}$, isosilybin $\mathrm{A}$ and $\mathrm{B}$, and three further components were partly separated, presumably two silybin stereoisomers and one isosilybin stereoisomer [26].
The aforementioned flavonoids possess several effects like antioxidant, anticancer and cell regenerating effect [7, 31-34]. Because of these properties, milk thistle has been used as an herbal medicine through centuries. Its usage covered treating liver and gallbladder diseases, and as an antidepressant, because of the historical theory that melancholy caused by "bad bile" or liver related problems [41]. Evidence based medicine started to investigate milk thistle in the second half of the $20^{\text {th }}$ century. A wide range of effects were explored by both topical and oral use. Silymarin has antiinflammatory and anti-erythmic effects [40], as well as potential in skin protection [8]. The antioxidant 
properties of silymarin inhibit oxidative stress and prevent skin cancer $[18,19]$. Topical silymarin can influence enzymatic (superoxide dismutase, catalase, glutathione peroxidase, glutathione reductase, glutathioneS-transferase) and non-enzymatic physiological defence systems of the skin, therefore decrease ROS (reactive oxygen species) production and, which is the main cause of oxidative stress, inflammation and skin cancer [5]. However, silymarin is mainly used orally, as an agent being hepato-protective, usable in prevention and treatment of cancer, gastrointestinal problems, cardiopulmonary problems, nephropathy, neuropathy, and being antidote of different toxins [13, 16, 25, 29]. As studies have shown, the effects of orally applied silymarin are including the stimulation of ribonucleic acid (RNA) polymerase I, ribosomal RNA synthesis and proteo-synthesis [45], free radical scavenging activity and ability to increase cellular glutathione level resulting in activity against lipid peroxidation, capacity to regulate nuclear expression, inhibition of myofibroblast formation from hepatocytes, and the ability to regulate membrane permeability and to increase membrane stability in the presence of xenobiotic damage [7].

Many articles were published about the background of the Silybum marianum effects, applications etc. Silybum marianum have been in focus of complex investigations, because of the small number of effective hepato-protective drugs on the market. One of the oldest formulation with silymarin as API is from the $1^{\text {st }}$ century, involving juice extract and honey [41]. Nowadays, oral administration of silymarin usually means conventional tablets or mainly capsules containing powdered milk thistle extracts. There are much less oil, syrup or suspension products on the market [53]. However, silymarin is poorly soluble in water, which leads to limited bioavailability and limited effective dosage forms. Improved preparations are needed to exploit the benefits fully [6]. Studies described 20 - 50 percent of the orally administered silymarin absorbed from the gastrointestinal tract, or even as low as $0.73 \%$ bioavailability in rat plasma $[12,49]$. Several researches targeted silymarin in the past years to increase its solubility and bioavailability. New silybin derivatives, liposomes and targeted liposomes, phytosomes, microemulsion and Self Micro-Emulsifying Drug Delivery Systems (SMEDDS), solid dispersion systems, different carriers such as lipid nanoparticles, polymeric micelles, or fulvic acid, floating tablets and micronization are all possibilities to bypass the problem of silymarin $[11,24,35,43$, 45, 50].

Complexation with liposomal structures, phospholipids or $\beta$-cyclodextrins is a way to increase solubility of drugs in the Class IV of the BCS (Biopharmaceutical Classification System. $\beta$-cyclodextrins are among the widely used host molecules for inclusion complexes $[2,10]$ studied the formulation of silymarin - $\beta$-cyclodextrin inclusion complexes with different methods. Their results suggest a 1:1 complex formation in the case of physical mixture. Stability constant was $722 \mathrm{~K}^{-1}$.

Summary of possibilities for increasing the bioavailability of

Table I
tages of each method [23-25, 44, 47, 48]

\begin{tabular}{|c|c|c|c|}
\hline & Possibility & Result & Disadvantage \\
\hline \multirow{3}{*}{$\begin{array}{l}\text { Chemical } \\
\text { modification }\end{array}$} & silybin derivatives & superior antioxidant properties possible & low water solubility \\
\hline & prodrug & even 30 times more soluble & lower hepato-protective potency \\
\hline & silybin glycoside & improved hepatic cell uptake and solubility & not the total extract \\
\hline \multirow[t]{2}{*}{ Complexation } & phospholipids & $\begin{array}{l}\text { increased absorption, lower therapeutic } \\
\text { dose, better stability profile }\end{array}$ & not the total extract \\
\hline & $\beta$-cyclodextrins & 6-times higher bioavailability in vivo & cell toxicity considerations \\
\hline \multirow[t]{3}{*}{$\begin{array}{l}\text { Conventional } \\
\text { dosage forms }\end{array}$} & floating tablets & prolonged gastric time & $\begin{array}{l}\text { dissolution in the stomach and not in the } \\
\text { small intestines }\end{array}$ \\
\hline & solid dispersions & higher solubility & instability considerations \\
\hline & micronization & enhanced dissolution rate & high energy requirements \\
\hline \multirow{5}{*}{$\begin{array}{l}\text { Novel dosage } \\
\text { forms }\end{array}$} & liposomes & enhanced gastrointestinal absorption & difficult in large scale manufacturing \\
\hline & nanoparticles & enhanced dissolution & toxicity considerations \\
\hline & microspheres & higher dissolution percentage & $\begin{array}{l}\text { released pharmacon still under } 60 \% \text { in } 36 \\
\text { hours }\end{array}$ \\
\hline & SMEDDS & more than 3-times higher bioavailability & $\begin{array}{c}\text { high content of surfactants can lead to } \\
\text { irritation }\end{array}$ \\
\hline & sustained release & controlled release of components & solubility and permeability still low \\
\hline
\end{tabular}

Sustained release formulations are a popular way to increase the efficiency of pharmacotherapy. This technology is easy to optimize, improves patient compliance and last, has a reasonable cost [28, 39]. Hydrophilic matrix systems assure controlled release, and have the advantages like the possibility to use conventional processes and equipment, and a wide range of active ingredients can be formulated. The polymers can swell in aqueous solution and form gel layer on the surface, leading to the extended release of the pharmacon $[9,36,37]$. Studies shown that formulation of silymarin in hydrophilic matrix 
systems could be a promising way to improve bioavailability of the herbal drug [28, 52]. The results of novel Silybum marianum investigations were summarised in the Table I, representing the new effective formulations from this plant extract. It can be concluded that there is a shortage of reliable oral formulations with a proper bioavailability for silymarin therapy. It leads to the lack of effective hepatoprotective therapy and the expected effects in the treatment of cancer, or at least unexploited possibilities in a very important field of modern medicine.

The aim of our study was to produce a hydrophilic matrix tablet containing cyclodextrin encapsulated silymarin, a system which combines the advantages of increased solubility and the sustained release. Different silymarin- $\beta$-cyclodextrin complexes were formulated and carbopol based matrix tablets were prepared. 20 combinations were prepared for the testing of physical parameters, and in vitro dissolution and cytocompatibility tests were carried out to qualify their reliability. In the end, we could make a suggestion to the most proper product, according to our results.

\section{Materials and Methods}

\section{Materials}

Silymarin. Silymarin powder from Silybum marianum seeds was prepared according to Kahol et al. [14]. The main steps of the method are cooling and powdering the milk thistle seeds, defatting the seed powder, extracting it with acetonitrile, concentrating the obtained silymarin under vacuum, stirring, drying and filtering the material, and further purifying with acetonitrile, followed by filtering and drying. The silymarin powder did not contain any solvent residue. The same bioactive flavonolignans were determined as in the standards with the help of HPLC-MS method $[26,33]$.

Matrix forming polymers. Carbopol 71G, Noveon ${ }^{\circledR}$ AA-1 Polycarbophil USP, Carbopol 974 P NF, and Carbopol 971P were purchased from The Lubrizol Corporation (Wickliffe, Ohio, USA) [36].

Complexing agents. (2-Hydroxy)propyl- $\beta$-cyclodextrin (DS $3 \pm 1$ ), Heptakis(2,6-di-O-methyl)- $\beta$-cyclodextrin, methylated $\beta$-cyclodextrin (DS $\sim 12$ ), and

Random methyl- $\beta$-cyclodextrin (DS 12) were obtained from CycloLab R\&D Ltd. (Budapest, Hungary).

Tablet's excipients. Mg-stearate, talc, dibasic Caphosphate, $\mathrm{KH}_{2} \mathrm{PO}_{4}, \mathrm{NaCl}, \mathrm{HCl}$, and $\mathrm{NaOH}$ were obtained from Hungaropharma. Ludipress ${ }^{\circledR}$ was obtained from BASF (Ludwigshafen, Germany).

Artificial gastric fluid. Ingredients of artificial gastric fluid were $2.0 \mathrm{~g} \mathrm{NaCl}$ and $80.0 \mathrm{~mL}$ of $1 \mathrm{M}$ hydrochloric acid per litter, in accordance with the European Pharmacopoeia $9^{\text {th }}$ Edition.

Artificial intestinal fluid. Ingredients of artificial intestinal fluid were $6.8 \mathrm{~g} \mathrm{KH}_{2} \mathrm{PO}_{4}$ per litter and $0.1 \mathrm{M} \mathrm{NaOH}$ solution was used for adjusting $\mathrm{pH}$ to 6.8 , in accordance with the European Pharmacopoeia $9^{\text {th }}$ Edition.

Cell culture. Caco-2 cells were used for cytotoxicity studies. The cell line was obtained from European Collection of Cell Cultures (ECACC, Public Health England, Salisbury, UK).

Cell culture medium. 3-(4,5-dimethylthiazol-2-yl)2,5-diphenyltetrazolium bromide (MTT), Dulbecco's Modified Eagle's Medium (DMEM), phosphate buffered saline (PBS), Trypsin-EDTA, Heat-inactivated foetal bovine serum (FBS), L-glutamine, non-essential amino acids solution, and penicillin-streptomycin were purchased from Sigma-Aldrich (St. Louis, Missouri, USA).

Methods

Tablet Compressing. Each product contained $70 \mathrm{mg}$ silymarin as active ingredient, which is the single dose for adults. Silymarin- $\beta$-cyclodextrin complexes were made by physical mixture method: the drug and the different $\beta$-CD derivatives were weighted accurately in the required molar quantities (1:1), and mixed together in a mortar. $150 \mathrm{mg}$ of carbopols were used in each tablet. As excipients of tablet pressing, $15 \mathrm{mg}$ of Mg-stearate, $5 \mathrm{mg}$ of talc, $10 \mathrm{mg}$ of dibasic Ca-phosphate, and the amount of Ludipress required for the total weight of $500 \mathrm{mg}$ per tablet. The excipients ensured the glidant, lubricant, antiadhesive and binding effects. Tablet ingredients were homogenized in mortar after being measured. For compressing, manual bench-top tablet press (Debrecen, Hungary) was used. Compressing force was $50 \mathrm{~N}$. Four different matrix tablets were produced with four carbopol types, and 16 different tablet combinations were prepared, the compositions are presented in Table II and III.

Table II

Composition of carbopol-based matrix tablets

\begin{tabular}{|l|l|l|l|l|}
\hline & 1. & 2. & 3. & 4. \\
\hline Silymarin & $70 \mathrm{mg}$ & \multicolumn{3}{l|}{} \\
\hline Mg-stearate & $15 \mathrm{mg}$ & \multicolumn{3}{l|}{} \\
\hline Talcum & $5 \mathrm{mg}$ & \multicolumn{3}{l|}{} \\
\hline Ca-phosphate dibasic & $10 \mathrm{mg}$ & & \\
\hline Ludipress & $250 \mathrm{mg}$ & & \\
\hline Carbopol 71G & $150 \mathrm{mg}$ & & & \\
\hline Noveon AA-1 Polycarbophil USP & & $150 \mathrm{mg}$ & & \\
\hline 971 PNF & & & $150 \mathrm{mg}$ & \\
\hline 974 PNF & & & & $150 \mathrm{mg}$ \\
\hline
\end{tabular}


Table III

Composition of matrix tablets containing cyclodextrin-complexed silymarin

\begin{tabular}{|c|c|c|c|c|c|c|c|c|c|c|c|c|c|c|c|c|}
\hline & 1. & 2. & 3. & 4. & 5. & 6. & 7. & 8. & 9. & 10. & 11. & 12. & 13. & 14. & 15. & 16. \\
\hline Silymarin & $70 \mathrm{mg}$ & & & & & & & & & & & & & & & \\
\hline Mg-stearate & $15 \mathrm{mg}$ & & & & & & & & & & & & & & & \\
\hline Talcum & $5 \mathrm{mg}$ & & & & & & & & & & & & & & & \\
\hline Ca-phosphate dibasic & $10 \mathrm{mg}$ & & & & & & & & & & & & & & & \\
\hline Ludipress & $61 \mathrm{mg}$ & & & & & & & & & & & & & & & \\
\hline Methylated B-CD DS-12 & $189 \mathrm{mg}$ & & & & & & & $189 \mathrm{mg}$ & & & $189 \mathrm{mg}$ & & & $189 \mathrm{mg}$ & & \\
\hline Heptakis (2,6-di-O- methyl)- $\mathrm{B}-\mathrm{CD}$ & & $189 \mathrm{mg}$ & & & $189 \mathrm{mg}$ & & & & & & & $189 \mathrm{mg}$ & & & $189 \mathrm{mg}$ & \\
\hline Random methyl B-CD & & & $189 \mathrm{mg}$ & & & $189 \mathrm{mg}$ & & & $189 \mathrm{mg}$ & & & & & & & $189 \mathrm{mg}$ \\
\hline (2-Hydroxy-propyl)- $\beta-C D$ & & & & $189 \mathrm{mg}$ & & & $189 \mathrm{mg}$ & & & $189 \mathrm{mg}$ & & & $189 \mathrm{mg}$ & & & \\
\hline Carbopol 71G & $150 \mathrm{mg}$ & & & & $150 \mathrm{mg}$ & & & & $150 \mathrm{mg}$ & & & & $150 \mathrm{mg}$ & & & \\
\hline Noveon AA-1 Polycarbophil USP & & $150 \mathrm{mg}$ & & & & $150 \mathrm{mg}$ & & & & $150 \mathrm{mg}$ & & & & $150 \mathrm{mg}$ & & \\
\hline $971 \mathrm{PNF}$ & & & $150 \mathrm{mg}$ & & & & $150 \mathrm{mg}$ & & & & $150 \mathrm{mg}$ & & & & $150 \mathrm{mg}$ & \\
\hline 974 PNF & & & & $150 \mathrm{mg}$ & & & & $150 \mathrm{mg}$ & & & & $150 \mathrm{mg}$ & & & & $150 \mathrm{mg}$ \\
\hline
\end{tabular}

\section{Pharmaceutical Tests}

Weight uniformity. For the test of tablet weight uniformity, 20 tablets were measured and the average weights were calculated. Then we investigated the deviation of the tablet weights from the average.

Friablity. Tablet friability was measured using an Erweka TA40 friability tester (Heusenstamm, Germany). After carefully dedusted, the sample of 20 tablets was accurately weighed, then it was put in the drum of the tester. After 100 rotations of the drum, the loose dust was removed from the surface of the tablets and the tablets were weighed again.

Hardness. Tablet hardness was measured using an Erweka TBH30M tablet hardness tester (Heusenstamm, Germany). We investigated the breaking force of the sample of 10 tablets and averaged the results. All the methods and equipment used for pharmaceutical tests are in accordance with the European Pharmacopoeia $9^{\text {th }}$ Edition.

Dissolution test

Dissolution studies were conducted using Erweka DT 800 Dissolution Tester (paddle method) (Heusenstamm, Germany). Dissolution medium was artificial intestinal fluid containing $6,8 \mathrm{~g} \mathrm{KH}_{2} \mathrm{PO}_{4}$ per litter. $0.1 \mathrm{M}$ $\mathrm{NaOH}$ solution was used for adjusting $\mathrm{pH}$ to 6.8 . Temperature of the medium was $37 \pm 0.5^{\circ} \mathrm{C}$ and it was constantly stirred through the tests, the paddle rotation speed was $100 \mathrm{rpm}$. Four replicates of each product were used, each tablet was put in $900 \mathrm{~mL}$ of medium. During the 13 hours of the tests, 16 samples were withdrawn, $4 \mathrm{~mL}$ each, with replacement of the medium.

For studies of dissolution in artificial gastric fluid, medium contained $2.0 \mathrm{~g} \mathrm{NaCl}$ and $80.0 \mathrm{~mL}$ of $1 \mathrm{M}$ hydrochloric acid per litter.

For the studies of dissolution in changing medium, we used the basket method of the dissolution tester. In the first hour, the tablets were in artificial gastric fluid as medium, and then we changed the medium to artificial intestinal fluid, and continued the test of the tablets for six hours more.

Silymarin concentration of the samples were measured by spectrophotometric method at $287 \mathrm{~nm}$ (Shimadzu
UV-1601 UV-VIS Spectrophotometer, Kyoto, Japan). For reference, $70 \mathrm{mg}$ silymarin or silymarin-cyclodextrin complex containing $70 \mathrm{mg}$ active pharmaceutical ingredient (API) was solved in water then filtered. Sample absorbances are expressed as the percentage of the reference.

Cells culturing

Caco-2 cells were used for cytotoxicity studies. The cell line was obtained from European Collection of Cell Cultures. Cells were grown in plastic cell culture flasks in Dulbecco's Modified Eagle's Medium, supplemented with $3.7 \mathrm{~g} / \mathrm{L} \mathrm{NaHCO}_{3}, 10 \%$ (v/v) heatinactivated foetal bovine serum (FBS), $1 \%(\mathrm{v} / \mathrm{v})$ nonessential amino acids solution, $1 \%(\mathrm{v} / \mathrm{v}) 1$-glutamine, $100 \mathrm{IU} / \mathrm{mL}$ penicillin, and $100 \mathrm{IU} / \mathrm{mL}$ streptomycin in an atmosphere of $5 \% \mathrm{CO}_{2}$ at $37^{\circ} \mathrm{C}$. Used medium was replaced with fresh in every 72 hours. The cells were maintained by regular passaging, and passage numbers were between 20 and 40 in case of cells used for cytotoxicity experiments [42].

MTT cell viability test

For the cytotoxicity tests, MTT (3-(4,5-dimethylthiazol-2-yl)-2,5-diphenyltetrazolium bromide) was used to determine the viability of Caco-2 cells. On flat bottom 96-well tissue culture plates, seeded at a density of 10,000 cells in each plate, cells were allowed to grow for 7 days in $\mathrm{CO}_{2}$ incubator, at $37^{\circ} \mathrm{C}$.

For testing carbopol cytotoxicity as matrix-forming component of different tablets alone, the medium was removed from the cells and carbopol solutions were added, followed by an incubation period of 30 minutes.

For testing the tablet biocompatibility, samples from the dissolution test were used to treat the cells. After it, samples were removed, and the cells were incubated for a further 3 hours in a medium contained MTT at a concentration of $0.5 \mathrm{mg} / \mathrm{mL}$. The purple formazan crystals produced by the cells were dissolved in isopropanol solution (isopropanol:1.0 N hydrochloric acid 25:1). The absorbance was measured at $570 \mathrm{~nm}$ against a $690 \mathrm{~nm}$ reference with FLUOstar OPTIMA Microplate Reader. The viability of cells was expressed as the percentage of the untreated control [30]. 


\section{Statistical analysis}

Data were analysed using GraphPad Prism (version 6.1, GraphPad Software Inc., San Diego, California, USA). To compare the groups in dissolution tests, two-way ANOVA (Tukey's test of additivity) was performed. First time of significant difference between two dissolution curves and the first time of significant differences between all the compositions were examined.

\section{Results and Discussion}

Pharmaceutical tests

Weight uniformity. Weight uniformity test resulted in maximum deviation less than the allowed $5 \%$. The highest deviation from the average weight was measured in the case of those tablets which contained Carbopol $71 \mathrm{G}$, especially the composition without cyclodextrin. Tablets containing Carbopol 974 PNF showed the lowest deviation from the average, even as low as $0.5 \%$. Results are depicted in Table IV and Table V. The table shows the average weight of 20 tablets of each compositions, and the maximum deviation.

Table IV

Weight uniformity of matrix tablets

\begin{tabular}{|l|c|c|c|c|c|}
\hline \multicolumn{7}{|c|}{ Weight uniformity I. } \\
\hline & $71 \mathrm{G}$ & Noveon & $971 \mathrm{PNF}$ & $974 \mathrm{PNF}$ & \\
\hline average & 504.8 & 497.9 & 496.1 & 494.8 & $(\mathrm{mg})$ \\
\hline deviation & \pm 17.5 & \pm 4.9 & \pm 8.6 & \pm 2.5 & $(\mathrm{mg})$ \\
\hline
\end{tabular}

Table V

Weight uniformity of matrix tablets containing cyclodextrin-complexed silymarin

\begin{tabular}{|l|c|c|c|c|c|c|c|c|c|}
\hline \multicolumn{8}{|c|}{ Weight uniformity II. } & \multicolumn{1}{c|}{. } & \\
\hline & 1. & 2. & 3. & 4. & 5. & 6. & 7. & 8. & \\
\hline average & 497.2 & 494.7 & 496.1 & 494.7 & 499.8 & 495.7 & 503.7 & 497.8 & $(\mathrm{mg})$ \\
\hline deviation & \pm 6.4 & \pm 5.6 & \pm 4.5 & \pm 2.4 & \pm 8.9 & \pm 9.4 & \pm 2.5 & \pm 4.9 & $(\mathrm{mg})$ \\
\hline & 9. & 10. & 11. & 12. & 13. & 14. & 15. & 16. & \\
\hline average & 499.3 & 504.8 & 495.4 & 497.3 & 498.1 & 497.4 & 500.7 & 497.9 & $(\mathrm{mg})$ \\
\hline deviation & \pm 7.8 & \pm 8.2 & \pm 5.9 & \pm 6.4 & \pm 7.3 & \pm 5.8 & \pm 7.4 & \pm 9.3 & $(\mathrm{mg})$ \\
\hline
\end{tabular}

Friability. In case of every tablet, friability loss was less than the allowed $1 \%$. The highest friability loss occurred in the case of tablets containing Carbopol $71 \mathrm{G}$, while the compositions containing the other three carbopols did not show significant difference in friability. Results are presented in Table VI and Table VII. Loss is the difference between the weight of 20 tablets before and after the 100 rotations in the friability testing drum, and is under $1 \%$ in every case.

Table VI

Friability of matrix tablets

\begin{tabular}{|l|c|c|c|c|c|}
\hline \multicolumn{5}{|c|}{ Friability I. } \\
\hline & $71 \mathrm{G}$ & Noveon & 971 PNF & 974 PNF & \\
\hline loss & 49.2 & 26.2 & 27.2 & 24.0 & $(\mathrm{mg})$ \\
\cline { 2 - 6 } & $\mathbf{0 . 5 4}$ & $\mathbf{0 . 2 9}$ & $\mathbf{0 . 2 7}$ & $\mathbf{0 . 2 6}$ & $\mathbf{\%}$ \\
\hline
\end{tabular}

Table VII

Friability of matrix tablets containing cyclodextrin-complexed silymarin

\begin{tabular}{|l|c|c|c|c|c|c|c|c|c|}
\hline \multicolumn{10}{|c|}{ Friability II. } \\
\hline & 1. & 2. & 3. & 4. & 5. & 6. & 7. & 8. & \\
\hline \multirow{2}{*}{ loss } & 53.9 & 28.7 & 33.7 & 27.7 & 45.9 & 30.7 & 30.2 & 34.8 & $(\mathrm{mg})$ \\
\cline { 2 - 11 } & $\mathbf{0 . 5}$ & $\mathbf{0 . 3 2}$ & $\mathbf{0 . 3 4}$ & $\mathbf{0 . 2 5}$ & $\mathbf{0 . 4 6}$ & $\mathbf{0 . 3 1}$ & $\mathbf{0 . 3}$ & $\mathbf{0 . 3 5}$ & $\mathbf{\%}$ \\
\hline \multirow{2}{*}{ loss } & 9. & 10. & 11. & 12. & 13. & 14. & 15. & 16. & \\
\cline { 2 - 11 } & 43.8 & 28.3 & 38.6 & 20.9 & 43.8 & 22.9 & 46.1 & 34.8 & $(\mathrm{mg})$ \\
\cline { 2 - 11 } & $\mathbf{0 . 4 4}$ & $\mathbf{0 . 2 8}$ & $\mathbf{0 . 3 9}$ & $\mathbf{0 . 2 1}$ & $\mathbf{0 . 4 4}$ & $\mathbf{0 . 2 3}$ & $\mathbf{0 . 4 6}$ & $\mathbf{0 . 3 5}$ & $\mathbf{\%}$ \\
\hline
\end{tabular}

Hardness. As for the hardness test, the tablets proven to be well compressed. Compositions with Carbopol $71 \mathrm{G}$ proved to be the softest tablets, while compositions containing the other three types of carbopol did not show significant difference in hardness. Results are depicted in Table VIII and Table IX. The results are expressed as the average force in Newton which was enough to break 10 tablets of each composition.
Table VIII

Hardness of matrix tablets

\begin{tabular}{|l|c|c|c|c|c|}
\hline \multicolumn{6}{|c|}{ Hardness I. } \\
\hline & $71 \mathrm{G}$ & Noveon & 971 PNF & 974 PNF & \\
\hline average & $\mathbf{3 2 7}$ & $\mathbf{4 9 3}$ & $\mathbf{4 9 3}$ & $\mathbf{4 9 2}$ & $\mathbf{N}$ \\
\hline
\end{tabular}

Considering the results of the pharmaceutical test, we can state that even though the use of a manual bench press as the equipment for tablet production, the physical parameters proven to be proper. All 
FARMACIA, 2019, Vol. 67, 5

our samples fulfilled the same requirements as the commercial pharmaceutical products.

Table IX

Hardness of matrix tablets containing cyclodextrincomplexed silymarin

\begin{tabular}{|l|c|c|c|c|c|c|c|c|c|}
\hline \multicolumn{7}{|c|}{ Hardness II. } \\
\hline & 1. & 2. & 3. & 4. & 5. & 6. & 7. & 8. & \\
\hline average & $\mathbf{3 3 7}$ & $\mathbf{4 8 8}$ & $\mathbf{4 8 9}$ & $\mathbf{4 8 7}$ & $\mathbf{3 4 2}$ & $\mathbf{4 7 3}$ & $\mathbf{5 0 8}$ & $\mathbf{4 7 6}$ & $\mathbf{N}$ \\
\hline & 9. & 10. & 11. & 12. & 13. & 14. & 15. & 16. & \\
\hline average & $\mathbf{3 1 6}$ & $\mathbf{4 8 4}$ & $\mathbf{5 1 0}$ & $\mathbf{4 8 0}$ & $\mathbf{3 1 0}$ & $\mathbf{4 9 5}$ & $\mathbf{4 8 7}$ & $\mathbf{4 8 6}$ & $\mathbf{N}$ \\
\hline
\end{tabular}

Carbopol cytotoxicity

Cytotoxicity of all the four carbopols were tested by MTT assay on Caco-2 cell line. Correlation was not found between cell viability and carbopol concentration. The concentration of the carbopol solutions were steadily increasing, the examined maximum concentration was $150 \mathrm{mg}$ of carbopol (the quantity one tablet contains) in $900 \mathrm{~mL}$ water. The highest cell viability occurred in the case of Noveon. Figure 1 shows the result of MTT assay in the function of carbopol concentration against the percentage of surviving cells. $100 \%$ was the cell survival in the case when cells were untreated. Each data point represents the mean \pm S.D., $\mathrm{n}=5$.

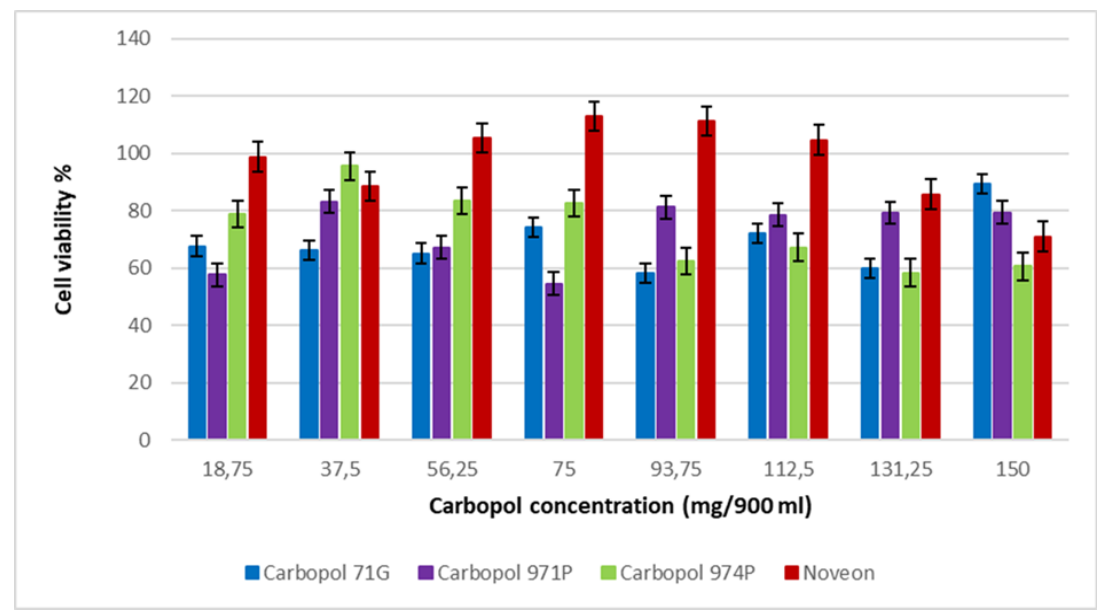

Figure 1.

Polymers MTT-cytotoxicity test

Dissolution of silymarin from matrix tablets

In the first series of dissolution tests, we examined the silymarin release from the carbopol-based hydrophilic matrix tablets. Results are shown in Figure 2. Each data point represents the mean \pm S.D. of four experiments. As we can see, all the four carbopols assured the sustained release of the silymarin. There was difference between the amount of released pharmacon, Carbopol
971P and Noveon being the two polymers with high amount of released silymarin after 780 minutes of dissolution. According to Tukey's test, the first significant difference occurred at 60 minutes between Carbopol 971P and 71G. At 780 minutes, all the 4 dissolution curves differed significantly from each other. Carbopols were proven suitable as the base of a sustained release hydrophilic matrix tablet.

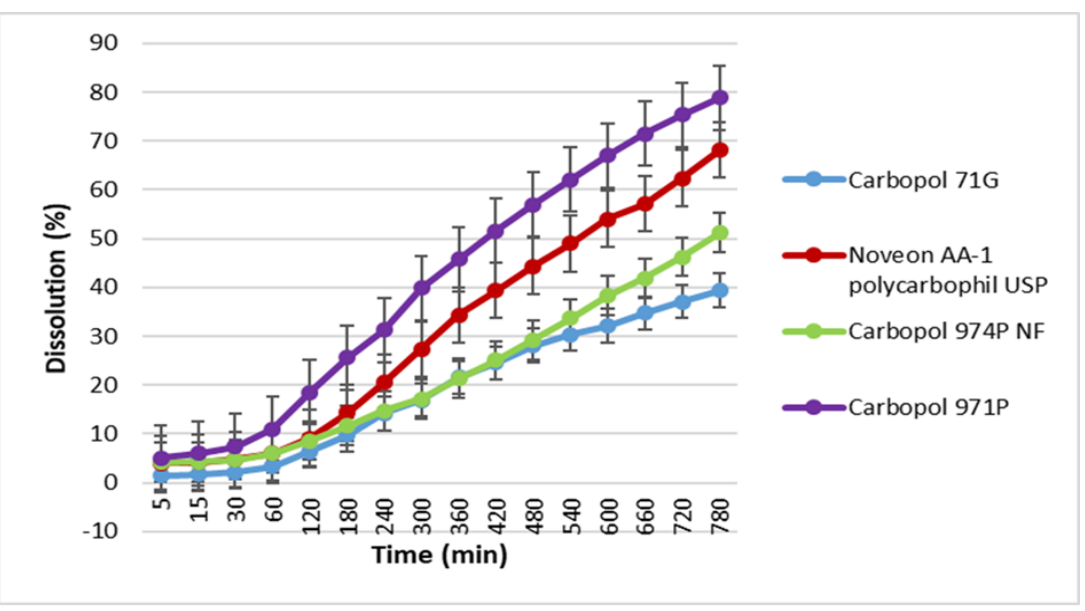

Figure 2.

Dissolution curves of carbopol based hydrophilic matrix tablets 
Dissolution of complexed silymarin from matrix

The second series of dissolution tests aimed to examine the pharmacon release in case of hydrophilic matrix technology combined with cyclodextrin complexation. We carried out the dissolution test for all the 16 combinations of the four types of $\beta$-cyclodextrin derivatives and the four carbopols. We compared the dissolution curves. Based on the test results, two of the carbopols (Noveon and Carbopol 974 PNF) were selected which shown the highest amount of released silymarin during the 780 minutes time period.
Dissolution curves of carbopol based hydrophilic matrix tablets containing silymarin complexed with randomly methylated $\beta$-cyclodextrin can be seen in Figure 3. Each data point represents the mean \pm S.D. of four experiments. The amount of released active ingredient was the highest in the case of Carbopol 974 PNF and Noveon. According to Tukey's test, the first significant difference occurred at 120 minutes between Carbopol 974 and $71 \mathrm{G}$, and between 974 and 971. Noveon and Carbopol 974 dissolution curves did not differed significantly until the end of the examination, according to the test.

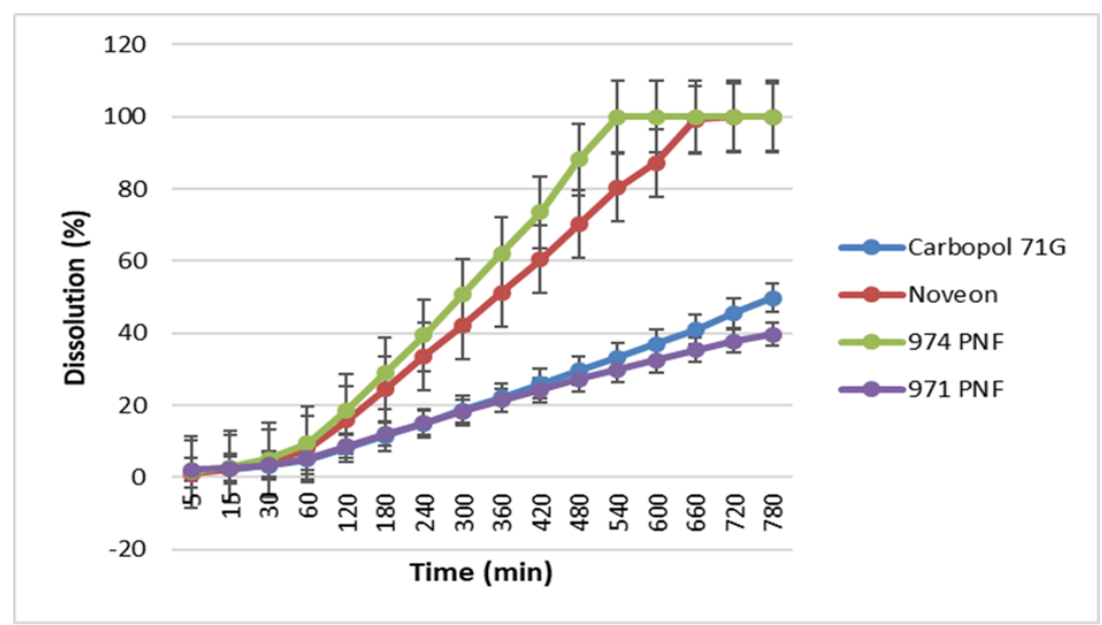

Figure 3.

Dissolution curves of carbopol based hydrophilic matrix tablets containing silymarin complexed with randomly methylated $\beta$-cyclodextrin

Dissolution curves of carbopol based hydrophilic matrix tablets containing silymarin complexed with Heptakis (2,6-di-O-methyl)- $\beta$-cyclodextrin can be seen in Figure 4. Each data point represents the mean \pm S.D. of four experiments. The amount of released active ingredient was the highest in the case of
Carbopol 974 PNF and Noveon. According to Tukey's test, the first significant difference occurred at 60 minutes between Carbopol 971 and Noveon. At 480 minutes, all the 4 dissolution curves differed significantly from each other.

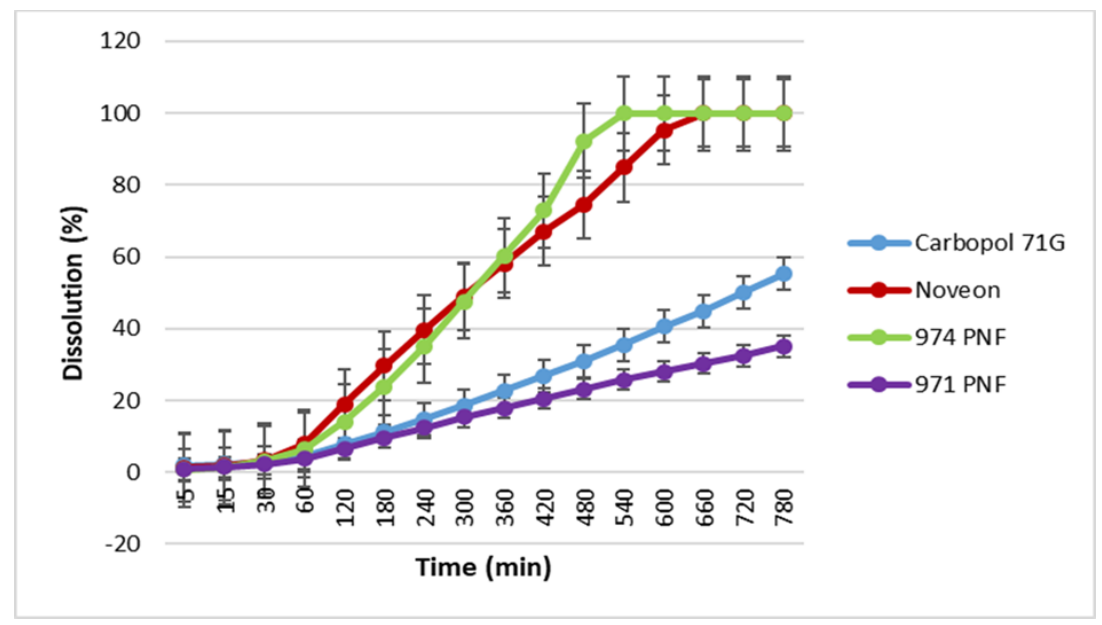

Figure 4.

Dissolution curves of carbopol based hydrophilic matrix tablets containing silymarin complexed with Heptakis (2,6-di-O-methyl)- $\beta$-cyclodextrin 
FARMACIA, 2019, Vol. 67, 5

Dissolution curves of carbopol based hydrophilic matrix tablets containing silymarin complexed with methylated $\beta$-cyclodextrin DS-12 can be seen in Figure 5. Each data point represents the mean \pm S.D. of four experiments. The amount of released active ingredient was the highest in the case of Carbopol
974 PNF and Noveon. According to Tukey's test, the first significant difference occurred at 180 minutes between Carbopol $71 \mathrm{G}$ and Noveon, 974. Noveon and Carbopol 974 dissolution curves did not differed significantly until the end of the examination, nor $71 \mathrm{G}$ and 971 , according to the test.

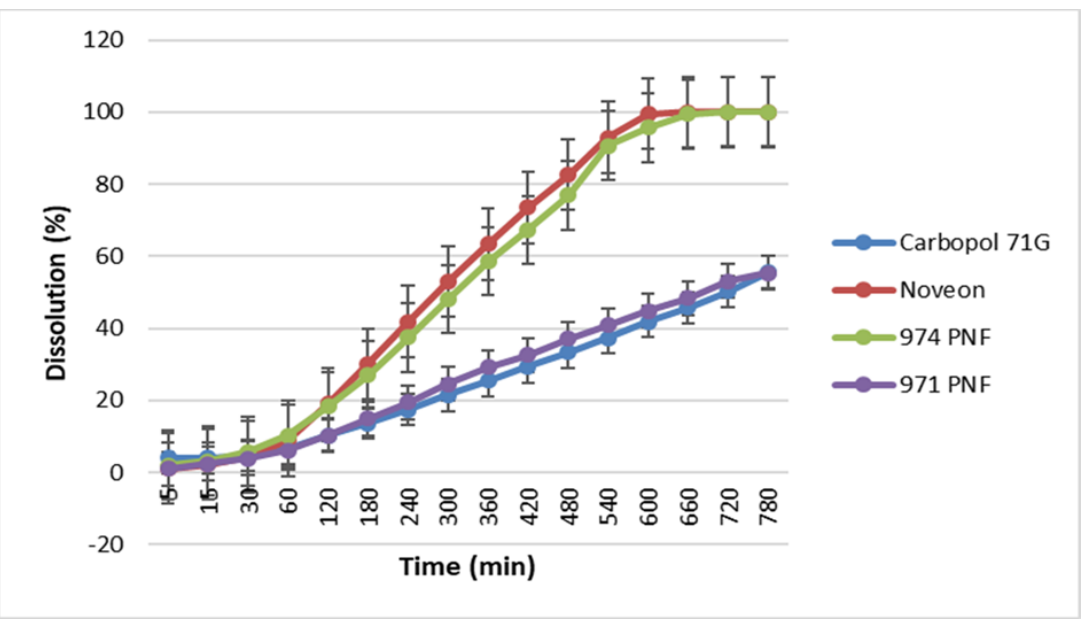

Figure 5.

Dissolution curves of carbopol based hydrophilic matrix tablets containing silymarin complexed with methylated $\beta$-cyclodextrin DS-12

Dissolution curves of carbopol based hydrophilic matrix tablets containing silymarin complexed with 2hydroxipropil $\beta$-cyclodextrin can be seen in Figure 6 . Each data point represents the mean \pm S.D. of four experiments. The amount of released active ingredient was the highest in the case of Carbopol 974 PNF and Noveon. According to Tukey's test, the first significant difference occurred at 60 minutes between Carbopol 974 and 71G, 971. At 240 minutes, all the 4 dissolution curves differed significantly from each other.

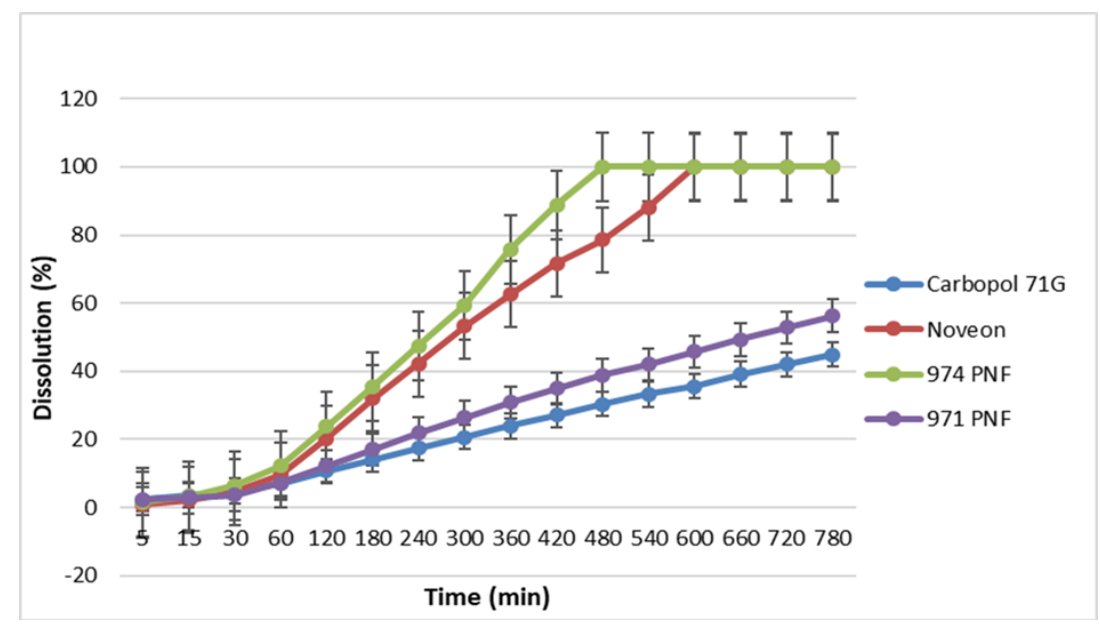

Figure 6.

Dissolution curves of carbopol based hydrophilic matrix tablets containing silymarin complexed with 2hydroxipropil $\beta$-cyclodextrin

\section{Dissolution in acidic medium}

In the third set of dissolution tests, we examined the silymarin release of carbopol based hydrophilic matrix tablets in artificial gastric juice. The pharmacon was complexed with hydroxy-propyl beta cyclodextrin. In this case, all carbopols shown the sustained drug release, but the dissolution was much slower in the process than in the previous tests with artificial intestinal fluid. In the end of the 780 minutes tests, the amount of dissolved silymarin was between $14 \%$ and $37 \%$. The dissolution curves are shown on Figure 7. Each data point represents the mean \pm S.D. 
FARMACIA, 2019, Vol. 67, 5

of four experiments. According to Tukey's test, the first significant difference occurred at 5 minutes between Noveon and Carbopol 974. Noveon and
Carbopol $71 \mathrm{G}$ dissolution curves did not differ significantly until the end of the examination, according to the test.

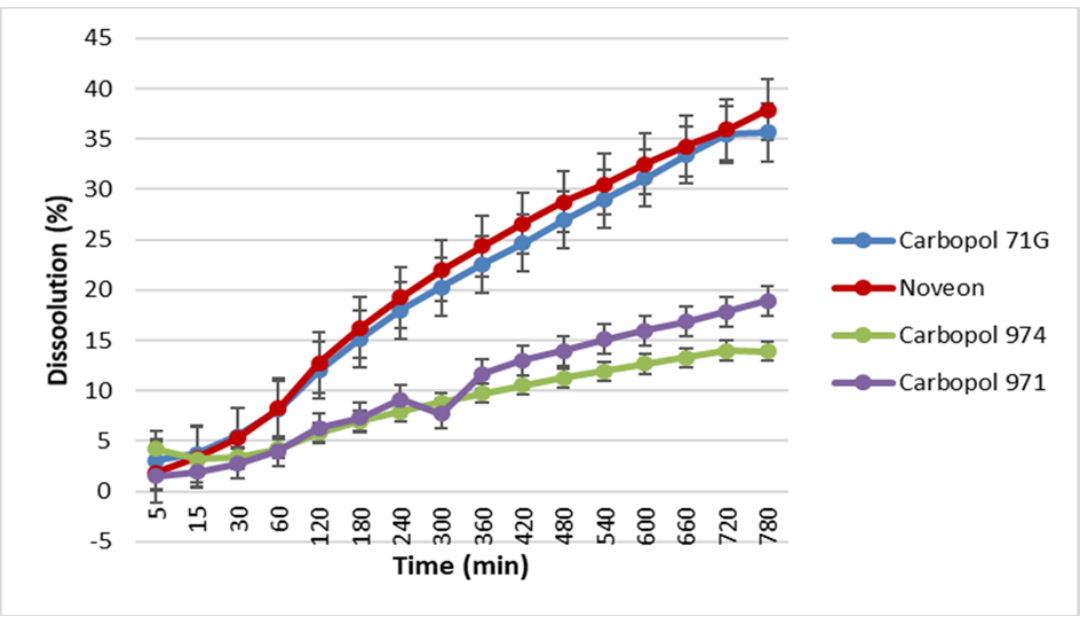

Figure 7.

Dissolution curves of carbopol based hydrophilic matrix tablets containing silymarin complexed with 2hydroxipropil $\beta$-cyclodextrin in artificial gastric juice, $\mathrm{pH}=1.2$

\section{Dissolution in altered medium}

In the fourth set of dissolution tests, the medium was artificial gastric juice in the first hour, and then we changed it to artificial intestinal fluid for six hours more. Our aim was to examine the behaviour of the carbopol matrix in an environment with $\mathrm{pH}$ conditions similar to the human GI system. We carried out the dissolution tests for all the 16 carbopol-cyclodextrin combinations. In these cases, the amount of released silymarin was less than the previous tests, partly because of shorter time, partly because of the acidic medium in the first hour, which affected the dissolution. Comparing the dissolution curves, we could find those combinations of carbopols and cyclodextrins which are supposed to have the best pharmacon release.

Dissolution curves of carbopol based hydrophilic matrix tablets containing silymarin complexed with methylated $\beta$-cyclodextrin DS-12 in altered medium can be seen in Figure 8. Each data point represents the mean \pm S.D. of four experiments. The amount of released active ingredient was the highest in the case of Carbopol 974 PNF and Noveon. The two other carbopols released only a low quantity of silymarin. According to Tukey's test, Carbopol 974 and Noveon differed significantly from 971 and $71 \mathrm{G}$ from the beginning of the examination, but not from each other until the end of examination.

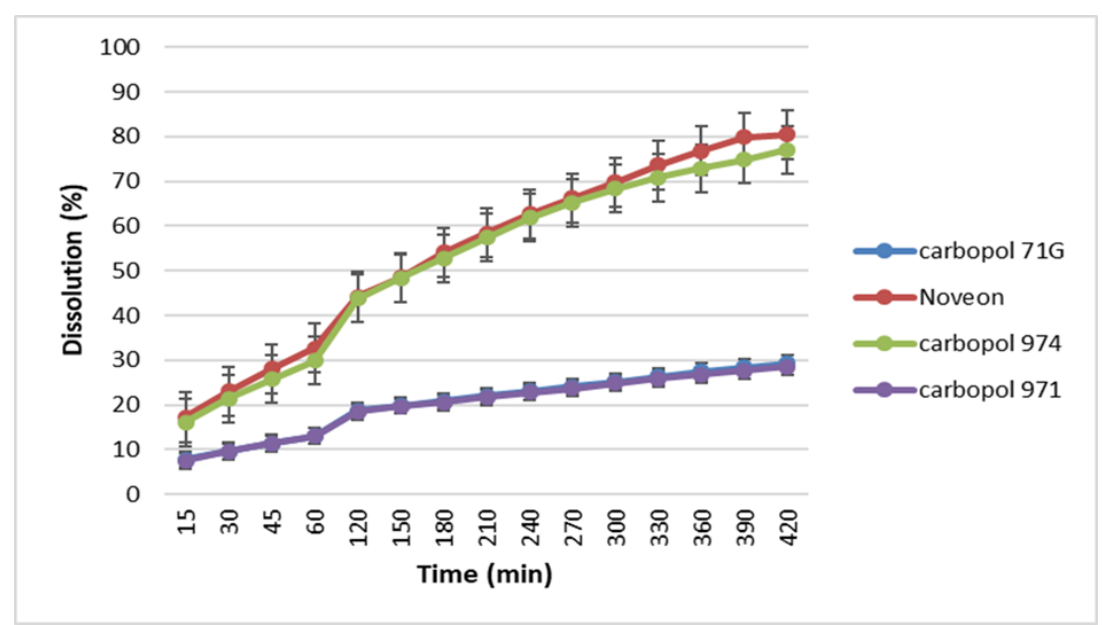

Figure 8.

Dissolution curves of carbopol based hydrophilic matrix tablets containing silymarin complexed with methylated $\beta$-cyclodextrin DS-12 in altered medium 
FARMACIA, 2019, Vol. 67, 5

Dissolution curves of carbopol based hydrophilic matrix tablets containing silymarin complexed with Heptakis (2,6-di-O-methyl)- $\beta$-cyclodextrin in altered medium can be seen in Figure 9. Each data point represents the mean \pm S.D. of four experiments. The amount of released active ingredient was the highest in the case of Carbopol 974 PNF and Noveon, but all of the four carbopols released only a low quantity of silymarin. According to Tukey's test, the first significant difference occurred at 15 minutes between Carbopol $71 \mathrm{G}$ and Noveon. Carbopol 971 and Carbopol $71 \mathrm{G}$ dissolution curves did not differ significantly until the end of the examination, according to the test.

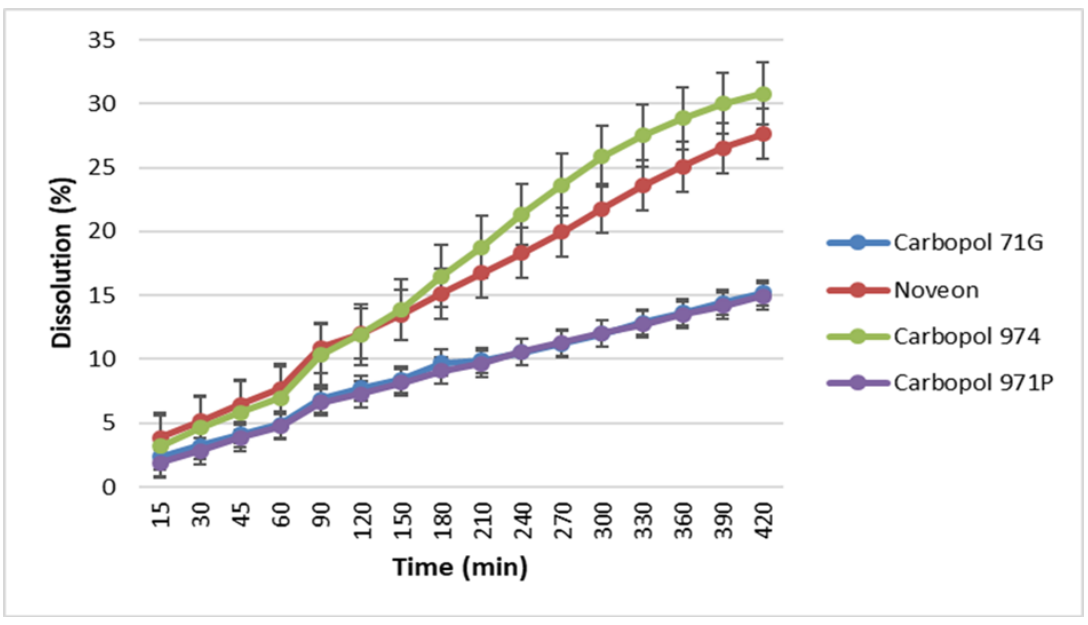

Figure 9.

Dissolution curves of carbopol based hydrophilic matrix tablets containing silymarin complexed with Heptakis (2,6-di-O-methyl)- $\beta$-cyclodextrin in altered medium

Dissolution curves of carbopol based hydrophilic matrix tablets containing silymarin complexed with randomly methylated $\beta$-cyclodextrin in altered medium are presented in Figure 10. Each data point represents the mean \pm S.D. of four experiments. The amount of released active ingredient was the highest in the case of Carbopol 974 PNF and Noveon, but all of the four carbopols released only a low quantity of silymarin. According to Tukey's test, the first significant difference occurred at 15 minutes between Carbopol $71 \mathrm{G}$ and 974. Carbopol 971 and Carbopol 71G dissolution curves did not differ significantly until the end of the examination, according to the test.

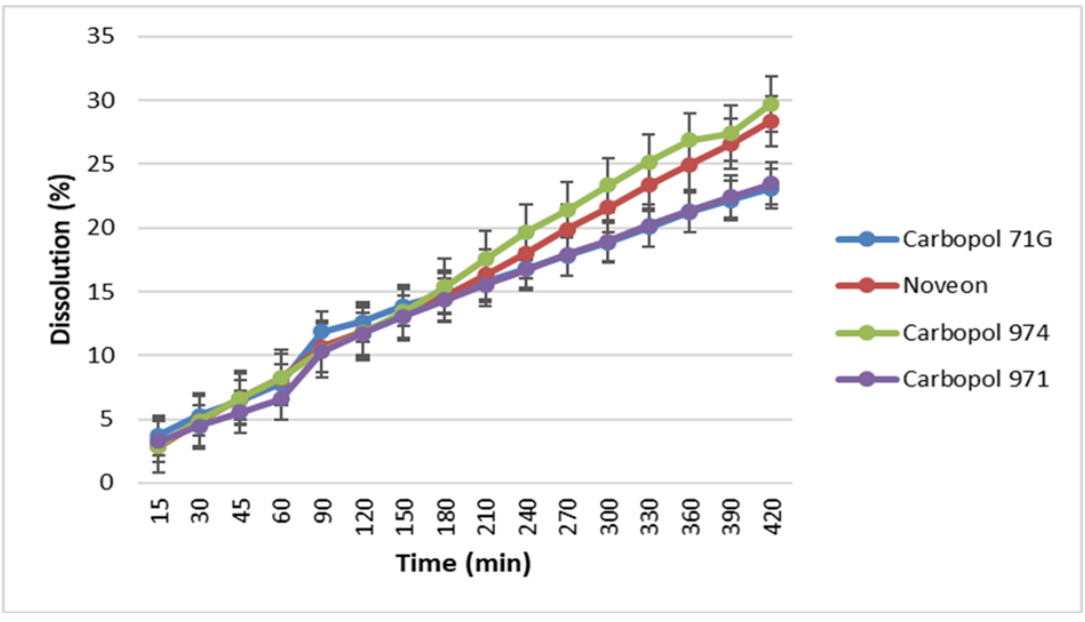

Figure 10.

Dissolution curves of carbopol based hydrophilic matrix tablets containing silymarin complexed with randomly methylated $\beta$-cyclodextrin in altered medium

Dissolution curves of carbopol based hydrophilic matrix tablets containing silymarin complexed with 2 -hydroxipropil $\beta$-cyclodextrin in altered medium are depicted in Figure 11. Each data point represents the mean \pm S.D. of four experiments. The amount of released active ingredient was the highest in the case of Carbopol 974 PNF and Noveon, but all of the four carbopols released only a low quantity of 
FARMACIA, 2019, Vol. 67, 5

silymarin. According to Tukey's test, the first significant difference occurred at 30 minutes between Carbopol $71 \mathrm{G}$ and 974. Carbopol 971 and Carbopol $71 \mathrm{G}$ dissolution curves did not differ significantly until the end of the examination, according to the test.

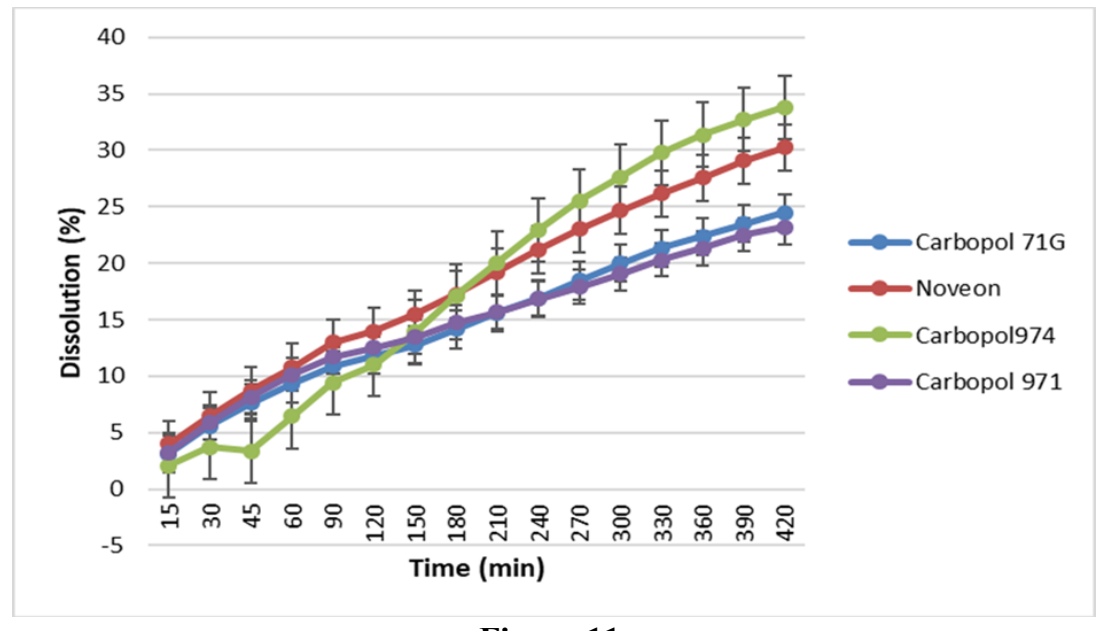

Figure 11.

Dissolution curves of carbopol based hydrophilic matrix tablets containing silymarin complexed with 2hydroxipropil $\beta$-cyclodextrin in altered medium

Dissolution of different silymarin preparations

Examining the results of the dissolution tests, two combinations of carbopols and cyclodextrins assuring the most favourable properties for sustained release and increased bioavailability of silymarin can be selected. We carried out the dissolution test in altered medium for a commercial product, which was a conventional capsule with $70 \mathrm{mg}$ silymarin as active ingredient. The dissolution curves of the commercial capsule and the Noveon and Carbopol 974 PNF based matrix tablets containing silymarin complexed with methylated $\beta$-cyclodextrin in both cases are shown in Figure 12. While the silymarin release of the conventional capsule peaked after the first hour, the matrix tablets implemented sustained release for six hours. The complexation with cyclodextrin increased the solubility of the active ingredient, resulting in a higher dissolved quantity. Each data point represents the mean \pm S.D. of four experiments. According to Tukey's test, the dissolution curve of the commercial product differs significantly from the matrix tablets since the $15^{\text {th }}$ minutes. The dissolution curves of the two matrix tablets did not differ significantly from each other until the end of the examination.

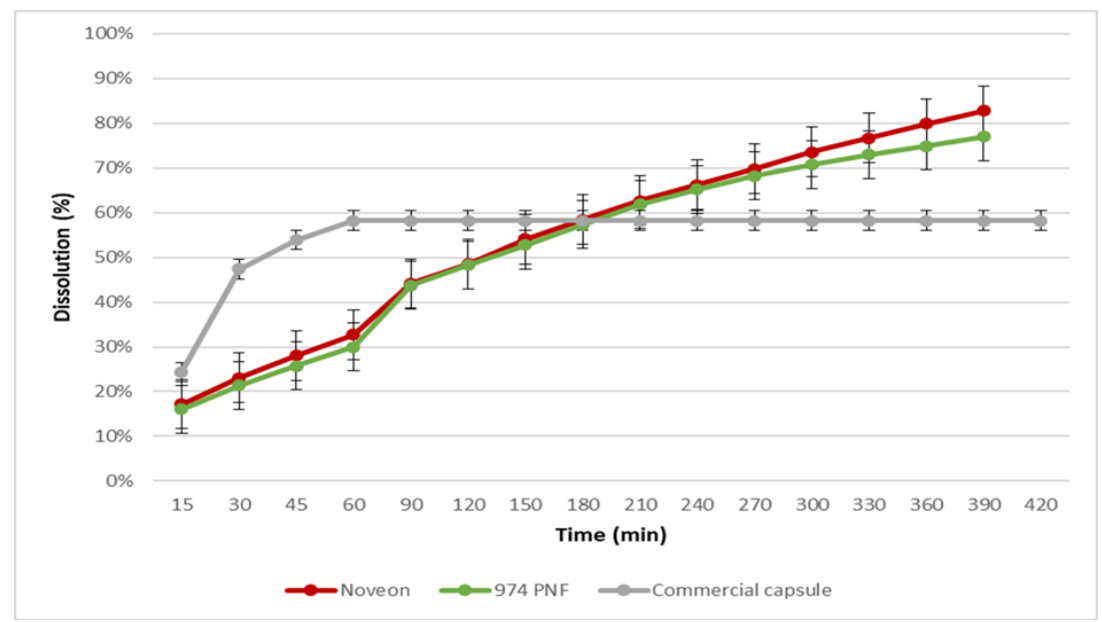

Figure 12.

Dissolution of the commercial capsule and the Noveon and Carbopol 974 PNF based matrix tablets containing silymarin complexed with methylated $\beta$-cyclodextrin in altered medium

Cytotoxicity test of Noveon based matrix tablets In the end, we repeated the dissolution test for the tablet containing the most suitable carbopol-cyclo- dextrin combination, Noveon and methylated $\beta$-cyclodextrin. Although there were no significant differences between the dissolution from the Noveon and Carbopol 
974 PNF, the former showed slightly higher amount of dissolved API. We used the samples taken during the test for an MTT assay. Results can be seen in Figure 13. Correlation was not found between the concentration of tablet components and the percentage of surviving cells. Cell viability was higher than $70 \%$ in case of each sample, and at certain points it was almost $100 \%$. The assay proved the tablet cytocompatible. Each data point represents the mean \pm S.D. of five experiments.

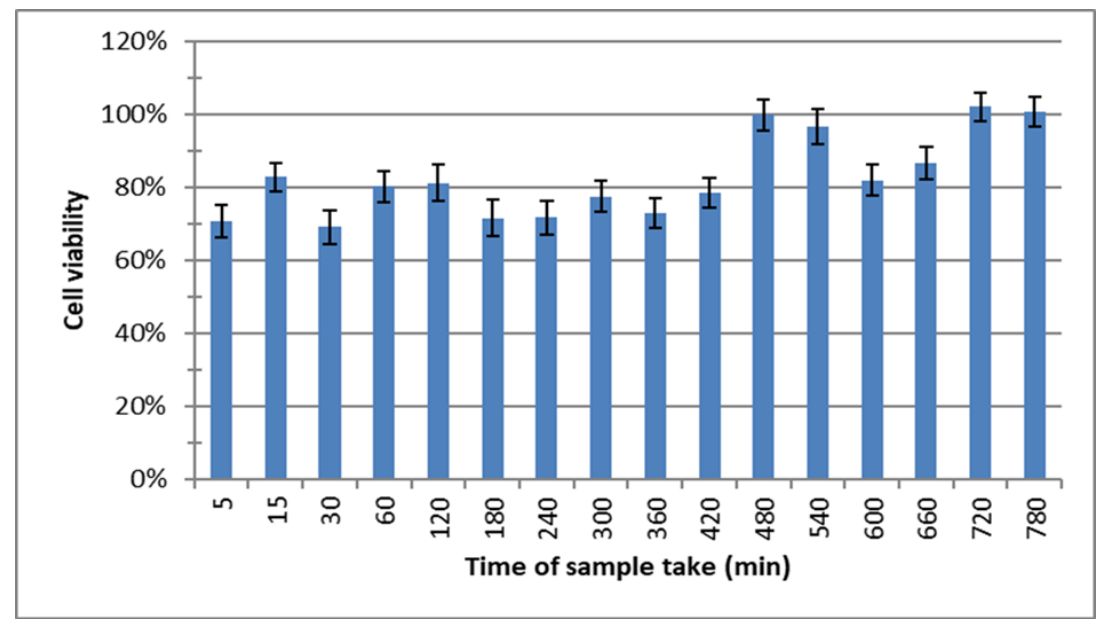

Figure 13.

MTT-cytotoxicity test results of Noveon based matrix tablets containing silymarin complexed with methylated $\beta$-cyclodextrin

Silymarin has a wide range of effects, hepatoprotective properties principally [38]. Being a natural pharmacon with negligible side effect, higher patient compliance can be expected for the therapy [13]. Although there are studies about pharmacons showing better hepatoprotectivity [15], silymarin is still one of the most potent agents on this field of medicine, and is definitely worth the attention of scientists. That was the reason that our aim was to prepare effective modified (sustained) release matrix tablets containing Silybum marianum herb extract for oral administration.

The main disadvantage of silymarin is its very low bioavailability, there are reviews reporting its limitations resulted in the lack of clinical efficacy [6]. There are several possibilities to improve bio-availability via solubility, permeability, metabolism, and excretion $[11,12]$.

In our study, different $\beta$-cyclodextrins were selected to increase the solubility profile of silymarin. Cyclodextrins are efficient excipients used in pharmaceutical industry for increasing solubility, bioavailability, stability and prevention of irritation and incompatibility in oral, rectal, nasal and transdermal drug delivery systems [46]. We used physical mixture method for complexation according to Ghosh et al. [10]. Although, the phase solubility data and the stability constant of $722 \mathrm{~K}^{-1}$ confirms this method, the number of different silymarin components leads to further concerns regarding to the actual compounds being complexed. However, investigations were carried out to examine the complexation of multicomponent herbal drugs. Despite the lack of stability constant or even the accurate inclusion complexes of compounds, Yeh et $a l$. proven the solubility enhancement and increased efficiency of San Huang Shel Shin Tang after complexation not only in vitro models, but in vivo experiments too [51]. We experienced that the solubility of Silybum marianum- $\beta$-cyclodextrin complex was $115 \%$ higher compared to the filtered solution of silymarin in the same quantity.

We chose hydrophilic matrix technology to assure sustained release. It is a relatively cheap method, and the production does not require special equipment, devices for producing conventional tablets are suitable. Several studies investigated the effect of $\beta$-cyclodextrin complexation combined with hydrophilic matrix technology, and proven enhanced bioavailability in the case of poorly soluble APIs like carbamazepine [22], nicardipine [1], diclofenac [17] and theophylline [38]. Carbopols are well-known materials used for topical gels, and their property of possessing carboxyl acid function makes their dissolution affected by the $\mathrm{pH}$ of the medium [37]. Our results showed that dissolution is decreased in lower $\mathrm{pH}$ from carbopol-matrix, which is favourable in the oral therapy leading to decreased quantity of active ingredient loss in the stomach. In addition, the result of cytotoxicity assays supported the cyto-compatibility of carbopols. The standard pharmaceutical tests showed that the physical parameters of our tablets are in accordance with the requirements of the European Pharmacopoeia $9^{\text {th }}$.

Considering the results of the dissolution tests, two compositions showing the best properties for a possible therapeutic use can be selected: the combinations of Noveon and Carbopol 974 PNF with methylated $\beta$ cyclodextrin. 
FARMACIA, 2019, Vol. 67, 5

There have been concerns for the toxicity of cyclodextrins for decades [3, 9, 27]. According to Kiss et al. $[20,21]$, there are differences in the cytotoxicty of different beta cyclodextrin derivatives in a concentration dependent manner. The results of our MTT-test may support of these investigations because the most suitable compositions showed highest cell viability proved the safety profile of our products.

\section{Conclusions}

Silymarin is worth the interest of scientific research considering not only its pharmacology and wide range of therapeutical effects, but the trend of high patient compliance toward natural and herbal medicines too.

The modern pharmaceutical technology offers several ways to overstep its limitations. Our research shows that combining $\beta$-cyclodextrins and carbopols, we can establish a sustained release system with enhanced solubility and sufficient biocompatibility, which can assure better therapeutic effects than the conventional commercial products in use and are relatively cheap and easy to produce.

\section{References}

1. Al-Zein H, Sakeer K, Alanaz FK, Designing an extended release waxy matrix tablet containing nicardipine-hydroxy propyl $\beta$ cyclodextrin complex. Saudi Pharmaceut J., 2011; 19(4): 245-253.

2. Ansari M, Investigations of polyethylene glycol mediated ternary molecular inclusion complexes of silymarin with beta cyclodextrins. J App Pharmaceut Sci., 2015; 5(9): 26-31.

3. Bellringer ME, Smith TG, Read R, Gopinath C, Olivier $\mathrm{P}$, beta-Cyclodextrin: 52-week toxicity studies in the rat and dog. Food Chem Toxicol., 1995; 33(5): 367-376.

4. Biedermann D, Vavrikova E, Cvak L, Kren V, Chemistry of silybin. Nat Prod Rep., 2014; 31: 1138-1157.

5. Fehér P, Ujhelyi Z, Váradi J, Fenyvesi F, Róka E, Juhász B, Varga B, Bombicz M, Priksz D, Bácskay I, Vecsernyés M, Efficacy of Pre- and Post-Treatment by Topical Formulations Containing Dissolved and Suspended Silybum marianum against UVB-Induced Oxidative Stress in Guinea Pig and on $\mathrm{HaCaT}$ Keratinocytes. Molecules, 2016; 21(10): 1269: 1-21.

6. Ferenci P, Silymarin in the treatment of liver diseases: What is the clinical evidence?. Clin Liver Dis., 2016; 7(1): 8-10.

7. Fraschini F, Demartini G, Esposti D, Pharmacology of silymarin. Clin Drug Invest., 2002; 22(1): 51-65.

8. Gazák R, Walterová D, Kren V, Silybin and Silymarin New and Emerging Applications in Medicine. Curr Med Chem., 2007; 14(3): 315-338.

9. Gergely V, Sebestyén G, Virág S, Toxicity Studies of Beta-Cyclodextrin. In: Szejtli J. (eds) Proceedings of the First International Symposium on Cyclodextrins. Advances in Inclusion Science, Springer, 1982; 1: 109-113.
10. Ghosh A, Biswas S, Ghosh T, Preparation and evaluation of silymarin $\beta$-cyclodextrin molecular inclusion complexes. J Young Pharm., 2011; 3(3): 205-210.

11. Javed S, Kohli K, Ahsan W, Solubility and Dissolution Enhancement of Silymarin with Fulvic Acid Carrier. Int J Drug Dev \& Res, 2016; 8(1): 009-014.

12. Javed S, Kohli K, Ali M, Reassessing Bioavailability of Silymarin. Altern Med Rev., 2011; 16(3): 239-249.

13. Jin J, Sklar GE, Oh VMS, Li SC, Factors affecting therapeutic compliance: A review from the patient's perspective. Ther Clin Risk Manag., 2008; 4(1): 269-286.

14. Kahol A, Singh K, Tandon S, Kumar S, Process for Isolation of Hepatoprotective Agent Silymarin from Seeds of the Plant Silybum marianum. Indian Patent, 06309678, 2001.

15. Kantah MK, Kumari A, He F, Sollano J, Alagozlu $\mathrm{H}$, Min CH, Lorenzetti A, Morita Y, Marotta F, An Orally-Bioavailable Glutathione-Based Hepatoprotective Compound in Experimental Acute Liver Injury: More Effective than Silymarin and YHK. $J$ Gastrointest Dig Syst., 2016; 6(4): 1000462: 1-5.

16. Karimi G, Vahabzadeh M, Lari P, Rashedinia M, Moshiri M, "Silymarin", a Promising Pharmacological Agent for Treatment of Diseases. Iran J Basic Med Sci., 2011; 14(4): 308-317.

17. Kasperek R, Zimmer L, Grochowicz M, Kierys A, Poleszak E, Matrix tablets formulation based on hydroxypropyl methylcellulose with $\beta$-cyclodextrin: characterization and evaluation of diclofenac sodium release. Acta Poloniae Pharmaceutica - Drug Research, 2017; 74(6): 1901-1911.

18. Katiyar SK, Meleth S, Sharma SD, Silymarin, a flavonoid from milk thistle (Silybum marianum L.), inhibits UV-induced oxidative stress through targeting infiltrating $\mathrm{CD} 11 \mathrm{~b}+$ cells in mouse skin. Photochem Photobiol., 2008; 84(2): 266-271.

19. Katiyar SK, Silymarin and skin cancer prevention: anti-inflammatory, antioxidant and immunomodulatory effects (Review). Int J Oncol., 2005; 26(1): 169-176.

20. Kiss T, Fenyvesi F, Bácskay I, Váradi J, Fenyvesi E, Iványi R, Szente L, Tósaki A, Vecsernyés M, Evaluation of the cytotoxicity of beta-cyclodextrin derivatives: evidence for the role of cholesterol extraction. Eur J Pharm Sci., 2010; 40(4): 376-380.

21. Kiss T, Fenyvesi F, Pasztor N, Feher P, Varadi J, Kocsan R, Szente L, Fenyvesi E, Szabo G, Vecsernyes M, Bacskay I, Cytotoxicity of different types of methylated beta-cyclodextrins and ionic derivatives. Pharmazie, 2007; 62(7): 557-558.

22. Koester LS, Xavier CR, Mayorga P, Bassani VL, Influence of beta-cyclodextrin complexation on carbamazepine release from hydroxypropyl methylcellulose matrix tablets. Eur J Pharm Biopharm., 2003; 55(1): 85-91.

23. Kosina P, Kren V, Gebhardt R, Grambal F, Ulrichová $\mathrm{J}$, Walterová $\mathrm{D}$, Antioxidant properties of silybin glycosides. Phytother Res., 2002; 16: 33-39.

24. Kren V, Kubisch J, Sedmera P, Glycosylation of silybin. J Chem Soc., 1997; 1: 2467-2474.

25. Kren V, Walterova D, Silybin and silymarin - new effects and applications. Biomed Pap Med Fac Univ Palacky Olomouc Chech Repub., 2005; 149(1): 29-41. 
FARMACIA, 2019, Vol. 67, 5

26. Kuki Á, Nagy L, Deák G, Nagy M, Zsuga M, Kéki S, Identification of Silymarin Constituents: An Improved HPLC-MS Method. Chromatographia, 2012; 75(3-4): 175-180.

27. Li P, Song J, Ni X, Guo Q, Wen H, Zhou Q, Shen Y, Huang Y, Qiu P, Lin S, Hu H, Comparison in toxicity and solubilizing capacity of hydroxypropyl$\beta$-cyclodextrin with different degree of substitution. Int J Pharm., 2016; 513(1-2): 347-356.

28. Liu ZH, Li XJ, Huang AW, Zhang J, Song HT, Preparation and Characterization of Silymarin Synchronized and Sustained Release Dropping Pill. Cur Drug Deliv., 2017; 14(5): 650-657.

29. Mahli A, Koch A, Czech B, Peterburs P, Lechner A, Haunschild J, Müller M, Hellerbrand C, Hepatoprotective effect of oral application of a silymarin extract in carbon tetrachloride-induced hepatotoxicity in rats. Clin Phytosci., 2015; 1: 5: 1-8.

30. Meerloo van J, Kaspers GJ, Cloos J, Cell sensitivity assays: the MTT assay. Methods Mol Biol., 2011; 731: 237-245.

31. Melikoglu G, Ozsoy N, Yilmaz-Ozden T, Erbay MS, Anil S, Celik BO, Kultur S, Flavonoids and biological activities of Centaurea nerimaniae $\mathrm{S}$. Kultur. Farmacia, 2018; 66(6): 1070-1075.

32. Pallag A, Jurca T, Sirbu V, Honiges A, Jurca C, Analysis of the amount of polyphenols, flavonoids and assessment of the antioxidant capacity of frozen fruits. Rev Chim (Bucharest), 2018; 69(2): 445-448.

33. Pîrvu L, Sha'at F, Miclea LC, Savopol T, Neagu G, Udeanu DI, Moisescu MG, Polygonum bistorta L. herba et flores. Polyphenols profile, antioxidant properties and cytotoxic effect on murine fibroblast cell line NIH3T3. Farmacia, 2017, 65(4): 571-576.

34. Pallag A, Paşca B, Jurca T, Suciu R, Nemeth S, Vicaş $\mathrm{L}$, Comparative histo-anatomical researches on the vegetative organs and assessment of antioxidant capacity of two species from Equisetum Genus. Farmacia, 2016; 64(3): 372-377.

35. Panapisal V, Charoensri S, Tantituvanont A, Formulation of microemulsion systems for dermal delivery of silymarin. AAPS PharmSciTech, 2012; 13(2): 389-399.

36. Patel K, Patel M, Bhatt N, Patel L, Pathak N, Patel K, An overview: extended release matrix technology. Int J Pharm Chem Sci., 2012; 1(2): 828-843.

37. Perez-Marcos B, Ford JL, Armstrong DJ, Elliott $\mathrm{PNC}$, Rostron $\mathrm{C}$, Hogan JE, Influence of $\mathrm{pH}$ on the release of propranolol hydrochloride from matrices containing Hydroxypropylmethylcellulose K4M and Carbopol 974. J Pharm Sci., 1996; 85(3) 330-334.

38. Pina ME, Veiga $F$, The influence of diluent on the release of theophylline from hydrophilic matrix tablets. Drug Dev Ind Pharm., 2000; 26(10): 1125-1128.

39. Pradhan SC, Girish C, Hepatoprotective herbal drug, silymarin from experimental pharmacology to clinical medicine, Ind J Med Res., 2006; 124(5): 491-504.

40. Rasul A, Akhtar N, Khan BA, Mahmood T, Zaman S, Atif A, Haji M, Khan S, Parveen S, Assessment of anti erythmic and skin whitening effects of milk thistle extract. Afr J Pharm Pharmacol., 2011; 5(20): 2306-2309.

41. Ross SM, Milk Thistle (Silybum marianum) An ancient botanical medicine for modern times. Holist Nurs Pract., 2008; 22(5): 299-300.

42. Sambuy Y, De Angelis I, Ranaldi G, Scarino ML, Stammati A, Zucco F, The Caco-2 cell line as a model of the intestinal barrier: influence of cell and culture-related factors on Caco-2 cell functional characteristics. Cell Biol Toxicol., 2005; 21(1): 1-26.

43. Samy AMA, Elmowafy M, Arafa M, Kari O, Viitala T, Kassem A, Abu-Elyazid SK, Ibrahim HM, Yliperttula M, Complement Activation Assay and In vivo Evaluation of Silymarin Loaded Liver Targeting Liposome. J Med Life, 2014; 2(1): 15-24.

44. Shangguan M, Lu Y, Qi J, Han J, Tian Z, Xie Y, Hu F, Yuan H, Binary lipids-based nanostructured lipid carriers for improved oral bioavailability of silymarin. J. Biomater Appl., 2014; 28(6): 887-896.

45. Theodosiou E, Purchartova K, Stamatis H, Kolisis FN, Kren V, Bioavailability of silymarin flavonolignans: drug formulations and biotransformation. Phytochem Rev., 2014; 13(1): 1-18.

46. Tiwari G, Tiwari R, Rai AK, Cyclodextrins in delivery systems: Applications. J Pharm Bioallied Sci., 2010; 2(2): $72-79$.

47. Ujhelyi Z, Fenyvesi F, Váradi J, Fehér P, Kiss T, Veszelka S, Deli M, Vecsernyés M, Bácskay I, Evaluation of cytotoxicity of surfactants used in self-micro emulsifying drug delivery systems and their effects on paracellular transport in Caco-2 cell monolayer. Eur J Pharm Sci., 2012; 47(3): 564-573.

48. Voinovich D, Perissutti B, Grassi M, Passerini N, Bigotto A, Solid state mechanochemical activation of Silybum marianum dry extract with betacyclodextrins: characterization and bioavailability of the coground systems. J Pharm Sci., 2009; 98(11): 4119-4129.

49. Wu JW, Lin LC, Hung SC, Chi CW, Tsai TH, Analysis of silibinin in rat plasma and bile for hepatobiliary excretion and oral bioavailability application. J Pharm Biomed Anal., 2007; 45(4): 635-641.

50. Yang G, Zhao Y, Feng N, Zhang Y, Liu Y, Dang B. Improved dissolution and bioavailability of silymarin delivered by a solid dispersion prepared using supercritical fluids. AJPS, 2015; 10(3): 194-202.

51. Yeh YL, Ting WJ, Kuo WW, Hsu HH, Lin YM, Shen CY, Chang CH, Padma VV, Tsai Y, San Huang Shel Shin Tang beta-cyclodextrin complex augmented the hepatoprotective effects against carbon tetrachlorideinduced acute hepatotoxicity in rats. BMC Complement Altern Med., 2016; 16: 150: 1-9.

52. Yin LF, Huang SJ, Wang XY, Zhang LY, Preparation and formulation optimization of silymarin sustainedrelease tablets. J China Pharm Univ., 2010; 41: 348-352.

53. www.druginfosys.com/drug. asp $x$ ?drugcode $=1013 \&$ type $=1$. 